\title{
Plutonium isotopes in the northwestern South China Sea Level, distribution, source and deposition
}

Zhang, Mengting; Qiao, Jixin; Zhang, Weichao; Zhu, Liuchao; Hou, Xiaolin

\section{Published in:}

Environmental Pollution

Link to article, DOI:

10.1016/j.envpol.2022.118846

Publication date:

2022

Document Version

Peer reviewed version

Link back to DTU Orbit

Citation (APA):

Zhang, M., Qiao, J., Zhang, W., Zhu, L., \& Hou, X. (2022). Plutonium isotopes in the northwestern South China Sea: Level, distribution, source and deposition. Environmental Pollution, 298, [118846]. https://doi.org/10.1016/j.envpol.2022.118846

\section{General rights}

Copyright and moral rights for the publications made accessible in the public portal are retained by the authors and/or other copyright owners and it is a condition of accessing publications that users recognise and abide by the legal requirements associated with these rights.

- Users may download and print one copy of any publication from the public portal for the purpose of private study or research.

- You may not further distribute the material or use it for any profit-making activity or commercial gain

- You may freely distribute the URL identifying the publication in the public portal 


\section{Journal Pre-proof}

Plutonium isotopes in the northwestern South China Sea: Level, distribution, source and deposition

Mengting Zhang, Jixin Qiao, Weichao Zhang, Liuchao Zhu, Xiaolin Hou

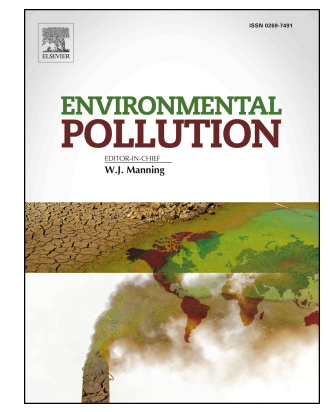

PII: S0269-7491(22)00060-4

DOI: $\quad$ https://doi.org/10.1016/j.envpol.2022.118846

Reference: $\quad$ ENPO 118846

To appear in: Environmental Pollution

Received Date: 12 October 2021

Revised Date: 5 January 2022

Accepted Date: 10 January 2022

Please cite this article as: Zhang, M., Qiao, J., Zhang, W., Zhu, L., Hou, X., Plutonium isotopes in the northwestern South China Sea: Level, distribution, source and deposition, Environmental Pollution (2022), doi: https://doi.org/10.1016/j.envpol.2022.118846.

This is a PDF file of an article that has undergone enhancements after acceptance, such as the addition of a cover page and metadata, and formatting for readability, but it is not yet the definitive version of record. This version will undergo additional copyediting, typesetting and review before it is published in its final form, but we are providing this version to give early visibility of the article. Please note that, during the production process, errors may be discovered which could affect the content, and all legal disclaimers that apply to the journal pertain.

() 2022 Published by Elsevier Ltd. 


\section{Author statement}

Mengting Zhang: Investigation, Methodology, Writing-original draft, Writing - review \& editing, Visualization.

Xiaolin Hou: Conceptualization, Writing - review \& editing, Validation, Supervision, Project administration, Funding acquisition.

Jixin Qiao: Conceptualization, Validation, Writing - review \& editing.

Weichao Zhang: Investigation, Writing - review \& editing.

Liuchao Zhu: Methodology. 


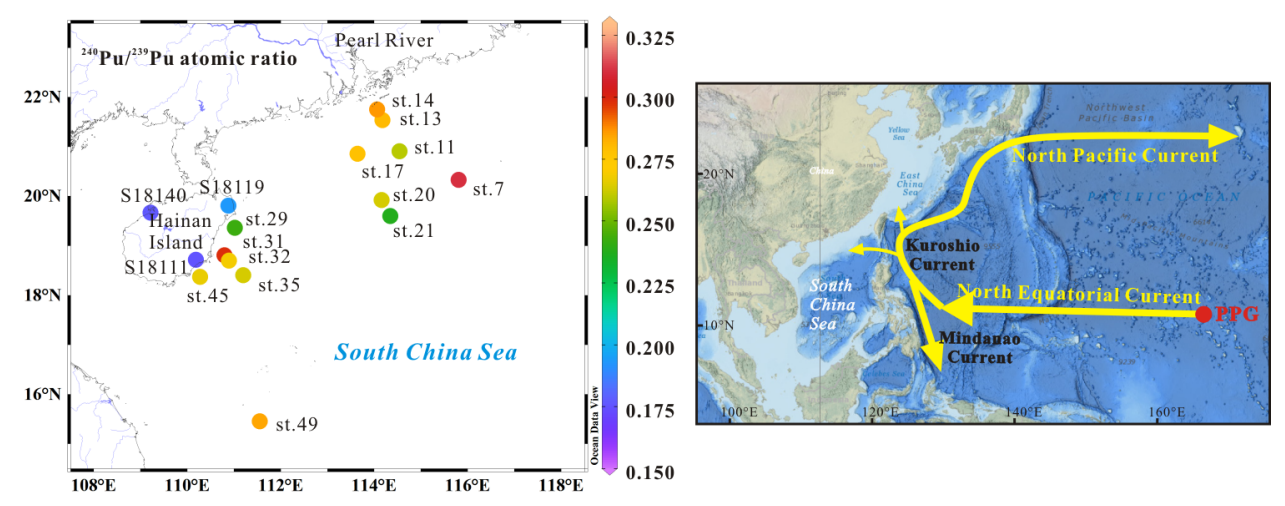




\section{Plutonium isotopes in the northwestern South China Sea: level,}

\section{2 distribution, source and deposition}

3

${ }^{a}$ State Key Laboratory of Loess and Quaternary Geology, Xi'an AMS Center, Institute of Earth Environment, Chinese Academy of Sciences, Xi'an 710061, Shaanxi Key Laboratory of Accelerator Mass Spectrometry Technology and Application, Xi'an 710061, P. R. China

${ }^{b}$ Department of Environmental Engineering, Technical University of Denmark, Risø Campus, Roskilde, 4000, Denmark

${ }^{c}$ Xi'an Institute for Innovative Earth Environment Research, Xi'an 710061, P. R. China

${ }^{d}$ Northwest Institute of Nuclear Technology, Xi'an 710024, P. R. China

${ }^{e}$ Open Studio for Oceanic-Continental Climate and Environment Changes, Pilot National Laboratory for Marine Science and Technology (Qingdao), Qingdao, 266061, P. R. China

\section{Abstract:}

The spatial distribution of plutonium isotopes $\left({ }^{239} \mathrm{Pu},{ }^{240} \mathrm{Pu}\right)$ in the surface sediments collected from the northwestern South China Sea (SCS) in 2018 was investigated. The ${ }^{239,240} \mathrm{Pu}$ concentrations in surface sediments vary from 0.048 to $0.960 \mathrm{mBq} / \mathrm{g}$ (with mean of $0.282 \pm 0.242 \mathrm{mBq} / \mathrm{g}$ ) depending on the geographical feature of the sampling location such as the river estuary, continental shelf, slope and deep basin. Higher ${ }^{240} \mathrm{Pu} /{ }^{239} \mathrm{Pu}$ atomic ratios $(0.24-0.31)$ in the surface sediment of the SCS compared to the global fallout value of 0.18 were observed, this is attributed to the input of close-in fallout of the Pacific Proving Ground (PPG) transported by the North Equatorial Current and Kuroshio Current to the northern SCS. The contribution of the PPG derived plutonium in the SCS sediment was estimated to be $39 \%-78 \%$ using a simple two-end member mixing model based on the measured ${ }^{240} \mathrm{Pu} /{ }^{239} \mathrm{Pu}$ atomic ratios in the

\footnotetext{
*Corresponding author: E-mail address: xiho@dtu.dk (Xiaolin Hou)
} 
sediment. Besides the soluble ${ }^{239,240} \mathrm{Pu}$ level in seawater, load of suspended particulate matter from the river runoff and biological debris, hydrographic and hydrodynamic conditions are key parameters influencing the deposition process of plutonium to the sediment.

Key Words: Plutonium, South China Sea, Pacific Proving Ground, Deposition, ${ }^{240} \mathrm{Pu} /{ }^{239} \mathrm{Pu}$ atomic ratio

\section{Introduction}

Plutonium is an important anthropogenic radionuclide in the environment, and ${ }^{239} \mathrm{Pu}\left(\mathrm{t}^{1} \frac{2}{2}=24,110 \mathrm{yr}\right)$ and ${ }^{240} \mathrm{Pu}\left(\mathrm{t}^{1 / 2}=6561 \mathrm{yr}\right)$ are the most important isotopes of plutonium, which have been widely used to estimate the environmental effects of human nuclear activities and to trace environmental processes, such as soil erosion and the behaviors of the suspending particles in the ocean (Zhang et al., 2019; Cao et al., 2021). It has been estimated that human nuclear activities including nuclear weapons tests, nuclear accidents and operation of nuclear facilities have released about $1.1 \times 10^{16} \mathrm{~Bq}$ of ${ }^{239,240} \mathrm{Pu}$ to the oceans (Aarkrog, 2003; Qiao et al., 2009). Plutonium isotopes $\left({ }^{238} \mathrm{Pu},{ }^{239} \mathrm{Pu},{ }^{240} \mathrm{Pu},{ }^{241} \mathrm{Pu}\right)$ are mainly produced through sequential neutron activation reactions of ${ }^{238} \mathrm{U}$ and ${ }^{235} \mathrm{U}$ with neutrons of different energies. The composition of plutonium isotopes, e.g. ${ }^{240} \mathrm{Pu} /{ }^{239} \mathrm{Pu}$ atomic ratios, is different depending on the plutonium sources. For example, weapons-grade plutonium shows very low ${ }^{240} \mathrm{Pu} /{ }^{239} \mathrm{Pu}$ atomic ratio of less than 0.05 (Smith et al., 1995), whereas relative high ratios of 0.23 - 0.67 were reported for plutonium originated from nuclear power reactors (Warneke et al., 2002). The average ${ }^{240} \mathrm{Pu} /{ }^{239} \mathrm{Pu}$ atomic ratio observed in the global fallout of atmospheric nuclear weapons tests was estimated to be $0.178 \pm 0.002$ (Kelley et al., 1999), while higher ratios of 0.33 - 0.36 in the close-in fallout in the Pacific Proving Grounds (PPG) (Krey et al., 1976; Buesseler, 1997; Muramatsu et al., 2001) and lower ratios of 0.05-0.13 in the close-in fallout in Johnston Atoll (the North Pacific) and Semipalatinsk testing sites (Kazakhstan) (Wolf et al., 1997; Wendel et al., 2013) were observed. Based on the ${ }^{240} \mathrm{Pu} /{ }^{239} \mathrm{Pu}$ atomic ratio fingerprint from different nuclear activities, the sources of plutonium could be identified and the contribution from different sources could be estimated (Wu et al., 2014; Zhang et al., 2019; Zhao et al., 2019).

A large number of investigations on plutonium isotopes in soil, sediments, seawater and coral in the Northern Hemisphere (Wang and Yamada, 2005; Zheng et al., 2012; Zhang et al., 2018; Xu et al., 2018; Wang et al., 2017; Liu et al., 2011, 2020; Wu et al., 2014; Dong et al., 2010; Roviello et al., 2020; Guan et al., 2021; Yamada et al., 2021) and Southern Hemisphere (Srncik et al., 2014; Tims et al., 2016) have been 
reported. Among of them, the marginal seas of the western Pacific Ocean, e.g. the Japan Sea, Bohai Sea, Yellow Sea, East China Sea and the South China Sea have attracted high attention for the potential transport of the close-in fallout of the Pacific Proving Grounds (PPG) with significantly higher ${ }^{240} \mathrm{Pu} /{ }^{239} \mathrm{Pu}$ atomic ratio compared to the global fallout signal. However, few investigation on plutonium isotopes in the northwestern South China Sea has been reported, the spatial distribution pattern and source term of plutonium in this region are unclear. The South China Sea (SCS) is one of the world's largest marginal seas, which is located in the southwest of the Northwest Pacific Ocean and semi-enclosed by mainland China in the north, Indonesia Islands in the south, Indochina Peninsula in the west, and Philippine Islands in the east. Up to $700 \mathrm{Mt} / \mathrm{yr}$ of continental suspended matters are injected to the SCS through numerous rivers, such as the Mekong River, the Red River, the Pearl River and Kaoping River(Liu et al., 2016). The level, distribution and sources of plutonium isotopes in the sediment samples in the northern SCS (Wu et al., 2014; Dong et al., 2010), seawater samples in the eastern and central SCS (Wu et al., 2018; Yamada et al., 2006) have been investigated. Nevertheless, investigation on the transport pathway and deposition process of plutonium from the overlying water column to surface sediment in different sites is still limited (Cao et al, 2021). Meanwhile, the factors influencing the spatial distribution of plutonium concentration and its isotopic ratio in the different marine environments have not been well investigated, which limited our unstanding on the behavior of the continential runoff sourced and long-distance sea current transported suspending particles.

This work aims to investigate the level and spatial distribution of ${ }^{239,240} \mathrm{Pu}$ in the northwestern South China Sea, to identify the sources of ${ }^{239,240} \mathrm{Pu}$, and to better understand its transport pathway and influence of hydrodynamic condition, suspended particulate matter and biogeochemical processes on the deposition and accumulation of plutonium in the sediment in different marine environments including estuarine, shelf and even deep-sea in the northwestern South China Sea.

\section{Material and methods}

\subsection{Sample collection}

Surface sediment samples $(0-5 \mathrm{~cm})$ were taken using box corer at 13 stations in the South China Sea (Fig. 1, Table 1) during the R/V "SHIYAN3" cruise in August and September 2018, and stored separately in plastic bags below $0{ }^{\circ} \mathrm{C}$ until analysis. The collected sediment samples were freeze dried in the laboratory before analysis. Surface soil samples $(0-5 \mathrm{~cm})$ were collected at 3 sites in Hainan Island in December 2018 
using a ring cutter of $7.0 \mathrm{~cm}$ in diameter (Fig. 1, Table 1). At each site, soil samples were collected from 3 points in an interval triangle of $1 \mathrm{~m}$ distance and mixed as one sample. The collected sample was stored in a plastic bag until analysis. After removal of stones and grass roots, the soil samples were first air-dried and then dried in an oven at $80^{\circ} \mathrm{C}$ until constant weight. The dried sediment and soil samples were ground and sieved through a 200 mesh sieve for analysis. .

\subsection{Sample analysis for plutonium isotopes}

The analytical method of plutonium isotopes in sediment and soil samples were modified from Xu et al. (2014). The detailed description of the separation method is presented in the Supporting Information (SI) and briefly presented here. The dried sediment or soil sample of 5-15 g was weighted to a beaker and ashed in an oven at $450 \square$ overnight, and the loss of the sample mass at this step(ignition loss) was recorded as approximately organic matter content in the sample (Table 1). ${ }^{242} \mathrm{Pu}(5.0 \mathrm{pg})$ prepared from standard solution (NIST-SRM-4334h) was ten spiked as a chemical yield tracer to the sample and mixed. After digestion with Aqua regia at $200^{\circ} \mathrm{C}$ and filtration, the plutonium was separated from matrix through co-precipitations with $\mathrm{Fe}(\mathrm{OH})_{3}$. After adjusting plutonium to $\mathrm{Pu}^{4+}$ and prepared in $\mathrm{HNO}_{3}$ medium, plutonium was separated from matrix and interfering elements using sequential anion exchange and extraction (TEVA resin) chromatography. The separated plutonium solution was prepared in $0.5 \mathrm{~mol} / \mathrm{L} \mathrm{HNO}_{3}$ and measured for ${ }^{239} \mathrm{Pu}$ and ${ }^{240} \mathrm{Pu}$ by ICP-MS/MS (Agilent 8800 ) with $\mathrm{NH}_{3}-\mathrm{He}$ as reaction-collision gas (Xing et al. 2018). With this technique, the tailing of ${ }^{238} \mathrm{U}^{+}$to $\mathrm{m} / \mathrm{z}$ of 239 and 240 was suppressed to be less than $1 \times 10^{-9}$, and the hydride interferences of ${ }^{238} \mathrm{U}^{1} \mathrm{H}^{+}$and ${ }^{238} \mathrm{U}^{1} \mathrm{H}_{2}{ }^{+}$to ${ }^{239} \mathrm{Pu}$ and ${ }^{240} \mathrm{Pu}$ were improved to be less than $3 \times 10^{-6}$. The uranium concentrations in the separated plutonium samples were also measured by ICP-MS and the contribution of ${ }^{238} \mathrm{U}$ tailing and uranium hydrides to the ${ }^{239} \mathrm{Pu}$ and ${ }^{240} \mathrm{Pu}$ signal were estimated to be less than $0.5 \%$. The chemical yields of plutonium in the separation procedure were measured using ${ }^{242} \mathrm{Pu}$ to be $73 \% \pm 16 \%$ $(n=16)$. The overall decontamination factors of $10^{5}-10^{6}$ for uranium were achieved in this work. The detection limits of this method for ${ }^{239} \mathrm{Pu}$ and ${ }^{240} \mathrm{Pu}$ in consideration of the interferences of ${ }^{238} \mathrm{U}^{+}$tailing and hydrides were estimated to be $0.1 \mathrm{fg} / \mathrm{mL}$ for ${ }^{239} \mathrm{Pu}$ and $0.05 \mathrm{fg} / \mathrm{mL}$ for ${ }^{240} \mathrm{Pu}$. The procedure blank was measured and subtracted for all plutonium results reported in this work.

\subsection{Analysis of grain-size of sediment}


Grain-size distribution of sediment samples was measured using a Malvern Mastersizer 3000 laser grainsize analyzer after removal of the organic matter, carbonates and particle dispersing (An et al., 2012; Sun et al., 2006). A detailed description of the method is presented in the Supporting Information (SI).

\section{Results and discussion}

\subsection{Level and spatial distribution of plutonium isotopes in surface sediment in the northwestern SCS}

The concentrations of ${ }^{239,240} \mathrm{Pu}$ (sum of ${ }^{239} \mathrm{Pu}$ and ${ }^{240} \mathrm{Pu}$ ) in 13 surface sediment samples in the northwestern SCS (Table 1) range from $0.048 \pm 0.008 \mathrm{mBq} / \mathrm{g}$ to $0.960 \pm 0.032 \mathrm{mBq} / \mathrm{g}$ (with a mean of 0.282 $\pm 0.242 \mathrm{mBq} / \mathrm{g}$ ), being similar to those observed in the surface sediment in the western Pacific Ocean (Fig. 2) (Zhang et al., 2018; Xu et al., 2018; Wang et al., 2017; Wang and Yamada, 2005; Wu et al., 2014; Dong et al., 2010; Moon et al., 2003; Yamada et al., 2021), which are two orders of magnitude lower than that near the Sellafield reprocessing plants (RP) and Pacific Proving Grounds (PPG) (Lindahl et al., 2011; Lachner et al., 2010).

The ${ }^{239,240} \mathrm{Pu}$ level in the analyzed surface sediments near the Pearl River estuary in the northern SCS showed a rapid increasing trend from $0.048-0.099 \mathrm{mBq} / \mathrm{g}$ in the deepwater zone (st.7 and st.21) to 0.960 $\mathrm{mBq} / \mathrm{g}$ in the shallow water (st.20) in the continental slope, and then decreased to a constant level of 0.258 $0.528 \mathrm{mBq} / \mathrm{g}$ towards to the continental shelf (st.11, st.13, st.14, st.17) (Fig.3a). This is similar to the reported trend of higher ${ }^{239,240} \mathrm{Pu}$ level in the continental shelf compared to that in the estuary of the Pearl River $(0.026-0.137 \mathrm{mBq} / \mathrm{g})\left(\mathrm{Wu}\right.$ et al., 2014). This indicates that ${ }^{239,240} \mathrm{Pu}$ in the sediment in the continental shelf might not only originated from the river input from the land but also transported by ocean currents from other areas.

The ${ }^{239,240} \mathrm{Pu}$ concentrations in surface sediments near the Hainan Island in the northwestern SCS show a decreasing trend from $(0.372-0.592 \mathrm{mBq} / \mathrm{g})$ at st.31, st.32 and st.35 in the outer shelf to $(0.071-0.195$ $\mathrm{mBq} / \mathrm{g}$ ) at st.29 and st.45 in the inner shelf, with all values higher than those in the surface soils from the Hainan Island (0.043-0.073 mBq/g) (S18111, S18119, S18140) (Fig.3a). The ${ }^{239,240} \mathrm{Pu}$ concentrations in the surface sediment from the southmost site at st. 49 in the deepest water zone (Bottom depth: $1256 \mathrm{~m}$ ) in this work were determined to be $0.173 \pm 0.021 \mathrm{mBq} / \mathrm{g}$, which agrees with the reported value $(0.157 \pm 0.010$ $\mathrm{mBq} / \mathrm{g}$ ) in the surface sediment collected in the SCS basin (Bottom depth: $4234 \mathrm{~m}$ ) in the surrounding area 


\subsection{Source term of plutonium in the northwestern SCS}

The ${ }^{240} \mathrm{Pu} /{ }^{239} \mathrm{Pu}$ atomic ratios in surface sediments in the northwestern SCS were between $0.237 \pm 0.050$ and $0.310 \pm 0.101$ (with a mean of $0.272 \pm 0.020, \mathrm{n}=13$ ) (Table 1 and Fig. 3b). While, significantly lower values of $0.175-0.193$ (with a mean of $0.181 \pm 0.008$ ) were measured in the 3 surface soil samples collected in the Hainan island (Table 1), which is comparable to the ratio in the global fallout of atmospheric nuclear weapons tests $\left(0.178 \pm 0.019,0-30^{\circ} \mathrm{N}\right)($ Kelley et al., 1999), indicating that plutonium in the soils in the Hainan Island originated from the global fallout. The significantly higher ${ }^{240} \mathrm{Pu} /{ }^{239} \mathrm{Pu}$ atomic ratios in the sediments investigated in this work compared to the level of the global fallout indicate significant contribution of other plutonium sources with higher ${ }^{240} \mathrm{Pu} /{ }^{239} \mathrm{Pu}$ atomic ratios in the northwestern SCS. Besides the global fallout, the possible sources of plutonium in the sediment in this area include the nuclear accidents (such as Chernobyl and Fukushima), discharges from nuclear facilities including nuclear power plants and reprocessing plants, close-in fallout of nuclear weapons tests and its long distance transport.

Although some nuclear power plants are located on the coast of China in the north SCS, no detectable plutonium in the surrounding area of these nuclear power plants has been detected (Zhang and Hou, 2019). To the best of our knowledge, there is no record of significant release of radioactive substances from any other nuclear facilities surrounding the investigated area. The contribution from these facilities to plutonium in our measured sediments is negligible.

It has been reported that some amount of plutonium has been released into the environment from the nuclear accidents, and higher ${ }^{240} \mathrm{Pu} /{ }^{239} \mathrm{Pu}$ atomic ratios of $0.386-0.412$ in the Chernobyl derived materials (Boulyga et al., 1997) and 0.323-0.330 in the Fukushima derived materials (Zheng et al., 2012) compared to the global fallout were measured. However, the region affected by the Fukushima derived plutonium was mainly within $30 \mathrm{~km}$ off the Fukushima Daiichi Nuclear Power Plant (FDNPP) (Zheng et al., 2012) and no significant increase of ${ }^{239,240} \mathrm{Pu}$ concentration in the environment near the FDNPP in $2012-2019$ was observed (Yamada et al., 2021). Plutonium as particle-associated radionuclide released from the Chernobyl accident was mainly deposited in surrounding areas of the Chernobyl, and no Chernobyl derived plutonium in soils from China and the marginal of Pacific Ocean has been reported (Wu et al., 2010; Wu et al., 2014). Other accidents such as those in Thule, Greenland and Palomares, Spain only contaminated the local areas. 
Hague (France) are unlikely to be transported to this region because of the long-distance and terrain barriers, and other reprocessing plants and nuclear facilities are also far from the investigated area, these sources can be also neglected.

The investigated region is far away from all nuclear weapons testing sites. The nearest testing site at Lop Nor is located at an inland area in northwest China and more than $3000 \mathrm{~km}$ north of the sampling sites, the close-in deposition on the soil in this site is difficult to be transported to southwards to the SCS. For other testing sites in the Pacific Ocean except for the Pacific Proving Grounds (PPG), the ${ }^{240} \mathrm{Pu} /{ }^{239} \mathrm{Pu}$ atomic ratios are less than 0.1 and lack the transport pathway of ocean current from these tests to the SCS, indicating a negligible contribution to the investigated region.

During 1946-1962, a hundred of atmospheric and underwater nuclear weapons tests were conducted in the Pacific Proving Grounds (PPG) (the Marshall Islands and surrounding areas) in the Pacific Ocean (5-10 ${ }^{\circ} \mathrm{N}, 165-172{ }^{\circ} \mathrm{E}$ ), which had resulted in the release of large amount of radioactive substances including plutonium to the environment. Plutonium released to the troposphere was mainly fell into the water in the surrounding areas as close-in deposition, which were rapidly removed from the water column to the sediment because plutonium is mainly associated with relative bigger particles comparing to those injected into the stratosphere as fine particles and dispersed globally (Buesseler, 1997; Buesseler and Sholkovitz, 1987). High plutonium concentrations have been observed in lagoon sediments in the Enewetak and Bikini Atolls with ${ }^{240} \mathrm{Pu} /{ }^{239} \mathrm{Pu}$ atomic ratios of 0.33-0.36 (Krey et al., 1976; Buesseler, 1997; Muramatsu et al., 2001). These contaminated sediments serve as reservoirs of tens of TBq transuranic and other radionuclides (Robison and Noshkin, 1999), where the deposited plutonium in the sediment was re-suspended/dissolved and continuously mobilized to pore/seawater and migrated to the above seawater in the local area (Robison and Noshkin, 1999). The circulation and exchange of seawater in the lagoons with the open ocean continuously export PPG derived plutonium with high ${ }^{240} \mathrm{Pu} /{ }^{239} \mathrm{Pu}$ atomic ratio to the North Equatorial Current (NEC), which flows westwards (Fig. 4). The advection rate of surface water in the NEC was estimated to be approximately $13-18 \mathrm{~km} / \mathrm{d}$, so it takes only several months for PPG derived plutonium signal to reach the western Pacific Ocean (Donaldson et al. 1997). The westwards flowing North Equatorial Current in North Pacific turns to the north when it reaches to the east coast of the Philippines Islands, and flow northward along the east coast of the Philippines Islands, Taiwan, and Japan to form the northward-flowing Kuroshio Current. A small branch of the Kuroshio Current (as a direct branch or loop current) carrying plutonium 
enters the SCS through the Luzon Strait (Hu et al., 2000). Being a particle reactive radionuclide, plutonium is readily deposited into the sediment by attaching to the suspending particles or integrated into biological debris.

The elevated ${ }^{240} \mathrm{Pu} /{ }^{239} \mathrm{Pu}$ atomic ratios observed in the SCS surface sediment in this work compared to the global fallout signal should be mainly attributed to the continuous input of the PPG derived plutonium. Many investigations also observed higher ${ }^{240} \mathrm{Pu} /{ }^{239} \mathrm{Pu}$ atomic ratios in the regions affected by Kuroshio Current (Wang and Yamada, 2005; Dong et al., 2010; Wu et al., 2014; Wang et al., 2017; Yamada et al., 2021). It was noticed that the highest ${ }^{240} \mathrm{Pu} /{ }^{239} \mathrm{Pu}$ atomic ratio $(0.31 \pm 0.10)$ was measured in the sediment at st. 7, which is located in the most east site to the Luzon Strait, reflecting a significant contribution of PPG derived $\mathrm{Pu}$. This also agrees with earlier observations of decreasing ${ }^{240} \mathrm{Pu} /{ }^{239} \mathrm{Pu}$ atomic ratios in surface sediments and seawaters from the vicinity of the Luzon Strait to the inner part of the SCS (Wu et al., 2018). It is therefore concluded that plutonium in the investigated region was mainly originated from two sources, i.e. global fallout of nuclear weapons testing and close-in fallout of the PPG.

The distribution of ${ }^{240} \mathrm{Pu} /{ }^{239} \mathrm{Pu}$ atomic ratios in the region near the Pearl River estuary shows a decreasing tendency from the open sea (e.g. st.7) to the continental shelf, reflecting the reduced influence of the Kuroshio Current. Meanwhile, ${ }^{240} \mathrm{Pu} /{ }^{239} \mathrm{Pu}$ atomic ratios decrease from the outer shelf towards the coast in the region near Hainan Island (Fig.3b). This is similar to the distribution pattern of ${ }^{239,240} \mathrm{Pu}$ concentrations, indicating an increasing fraction of global fallout in the coastal region. The global fallout derived plutonium includes direct atmospheric fallout of the nuclear weapon tests to the seawater which was transported to this region and further deposited to the sediment as particles and riverine input from the catchment areas after being removed from the soil surface through rainwater leaching and erosion processes.

Based on the measured ${ }^{240} \mathrm{Pu} /{ }^{239} \mathrm{Pu}$ atomic ratios in the sediment samples and the specific atomic ratios of ${ }^{240} \mathrm{Pu} /{ }^{239} \mathrm{Pu}$ for global fallout $(0.18)$ and PPG $(0.36)$, the relative contributions of global fallout and PPG close-in fallout to the plutonium in the SCS sediments in this work were estimated using a simple two endmember mixing model (Krey et al. 1976):

$$
\frac{\mathrm{Pu}(\mathrm{PPG})}{\mathrm{Pu}(\mathrm{Global})}=\frac{\left(R_{2}-R\right)\left(1+3.674 R_{1}\right)}{\left(R-R_{1}\right)\left(1+3.674 R_{2}\right)}
$$


$\mathrm{Pu}(\mathrm{PPG})$ and $\mathrm{Pu}(\mathrm{Global})$ are the relative percentage of the plutonium in surface sediments attributed to PPG close-in fallout and global fallout, respectively. $R$ is the ${ }^{240} \mathrm{Pu} /{ }^{239} \mathrm{Pu}$ atomic ratio measured in the surface

222 sediment in the SCS; $R_{1}$ is the representative ratio of ${ }^{240} \mathrm{Pu} /{ }^{239} \mathrm{Pu}$ from the PPG close-in fallout $(0.36)$ (Diamond et al., 1960; Buesseler, 1997); $R_{2}$ is the representative ${ }^{240} \mathrm{Pu} /{ }^{239} \mathrm{Pu}$ atomic ratio of global fallout (0.18) (Kelley et al., 1999; Krey et al., 1976). A factor of 3.674 is used to convert the atomic number (used in ${ }^{240} \mathrm{Pu} /{ }^{239} \mathrm{Pu}$ ratio) to activities of ${ }^{239} \mathrm{Pu}$ and ${ }^{240} \mathrm{Pu}$.

The estimated contributions from PPG derived plutonium in the surface sediment in the SCS vary from $39 \%$ to $78 \%$ (with an average of 59\%) (Fig. 5), reflecting the different transport and deposition of plutonium in the corresponding sedimentary environments in the SCS after the entrance of the branch of Kuroshio Current carrying PPG derived plutonium. This is in agreement with the reported PPG contributions in the sediment in the northern SCS shelf $(\sim 58 \%)$, the central SCS $(\sim 57 \%)$ and the Okinawa Trough $(\sim 56 \%)(\mathrm{Wu}$ et al., 2014; Dong et al., 2010; Wang and Yamada, 2005), and slightly higher than those in the East China Sea Shelf ( 41\%), the Japan Sea ( 43\%) (Wang et al., 2017; Yamada et al., 2021).

\subsection{Deposition of plutonium from seawater column to the sediment in the northwestern}

\section{SCS}

The deposition process of plutonium in the sea is related not only to the species of plutonium in the water body, but also the property of the water body such as load of suspending particles and its size, redox condition of water and biological activity. The basic property controlling the oceanic behavior of plutonium is its tendency to associate with particulate matters (Sholkovitz, 1983), which depends on the valence states of plutonium and loading amount of particles in the seawater (Livingston et al., 2001). The higher oxidation states $\mathrm{Pu}(\mathrm{V}, \mathrm{VI})$ have substantially less particle association than the lower valence states $\mathrm{Pu}$ (III, IV). It was reported that most of the dissolved plutonium (80\%) in seawater near the Marshall Island presented as $\mathrm{Pu}$ (V, VI) forms (Noshkin and Wong, 1979), which have a long residence time in the ocean and can be transported to the western Pacific Ocean through the NEC and Kuroshio Current. Meanwhile, the dissolved plutonium was gradually transferred to the sediment with the change of the hydrodynamic condition, suspended particulate matter and biogeochemical process in the water columns.

The deposition of particulate matters is dominated by the hydrodynamic condition in the water environment (Folk and Ward, 1957). Higher hydraulic energy mainly occurs in the shallow water in the nearshore zone with coarser suspending particles compared to the deep water in the offshore zone. Therefore, 
the grain size, especially the median grain size in the sediment, reflects the hydrodynamic strength in the above water column. The largest size grains (median grain size) were observed in the sediment collected near the estuary sites and the finest size grains in the sediment from the deep basin in this work (Table 2). The influence of the biogeochemical process on the deposition could be revealed by the organic content of the sediment, which is often estimated by the ignition loss. The measured ignition losses of the investigated sediments (Table 1) show that the sediment collected from the site with the deepest water has the highest organic matter content. It has been shown that up to $50 \%$ of plutonium could be associated with organic substances in environmental soil and sediment (Qiao et al., 2012). The incorporation of the plutonium with plankton in the western Mediterranean Sea has shown that phytoplankton might associate with transuranic elements by absorption with organic complexes or by adsorption of fine particles, such as colloids (SanchezCabeza et al., 2003). Zooplankton may be contaminated by active ingestion of phytoplankton, the debris of degraded phytoplankton and zooplankton is finally deposited to the bottom sediments. The suspending biological debris with inorganic particles fallout from the atmosphere and from the land through river input could also adsorb plutonium in the water and bring it to the sediment (Sanchez-Cabeza et al., 2003). Thus, the content of organic matter (ignition loss) in the sediment also reflects the strength of transformation/deposition of plutonium through the biogeochemical process. The riverine input of plutonium (primarily from global fallout) associated with particles leached from the soil in the catchment area is another important source of plutonium in the sediment. Meanwhile, the riverine particles can also scavenge ${ }^{239,240} \mathrm{Pu}$ from the water column into the sediment. Transport and deposition processes of plutonium from the global fallout and PPG in the South China Sea is illustrated in Fig. 6.

It was reported that the particulate associated ${ }^{239,240} \mathrm{Pu}$ accounts for about $85 \%$ of the total plutonium in river water due to the high partition coefficient of plutonium (ca. $4 \times 10^{5}$ ) (Hirose et al., 1990), which result in that plutonium in the estuarine sediment was mainly originated from the suspended particulate matter. A relative low ${ }^{239,240} \mathrm{Pu}$ level in the surface soil $(0.003-0.116 \mathrm{mBq} / \mathrm{g})$ has been reported (Zhang et al., 2019), and most ${ }^{239,240} \mathrm{Pu}$ (above $85 \%$ ) was integrated in the surface layer $(0-5 \mathrm{~cm})$ in the soil core (Xu et al., 2013). Therefore, the ${ }^{239,240} \mathrm{Pu}$ concentrations in the suspended particulate matter from the riverine input were relative low. The high average annual sediment discharge of the Pearl River $\left(8.43 \times 10^{7}\right.$ tons/yr) (Zhang et al., 2012) and low ${ }^{239,240} \mathrm{Pu}$ concentrations of the suspended particulate matter resulted in a low ${ }^{239,240} \mathrm{Pu}$ concentrations in the riverine originated sediment. This agree with the report that the riverine particles 
dominate the sediment within $\sim 75 \mathrm{~km}$ off the Pearl River estuary (Wu et al., 2014). The higher ${ }^{239,240} \mathrm{Pu}$ level observed in the surface sediment in the northern SCS shelf $(\sim 0.355 \mathrm{mBq} / \mathrm{g})$ compared to the reported value in the surface sediment in the Pearl River estuary (0.026-0.137 mBq/g) (Wu et al., 2014) shows that plutonium in the surface sediment in the continental shelf of the northern SCS was less affected by the riverine input but mainly by other sources of plutonium.

The relatively lower ${ }^{239,240} \mathrm{Pu}$ concentrations in the surface sediment at st.29 and st.45 near the Hainan Island $(0.071-0.195 \mathrm{mBq} / \mathrm{g})$ compared to those in the continental shelf $(0.372-0.592 \mathrm{mBq} / \mathrm{g})$ were observed. The similarly low ${ }^{239,240} \mathrm{Pu}$ concentrations of $0.043-0.073 \mathrm{mBq} / \mathrm{g}$ were also measured in the surface soil in the Hainan Island (Table 1). This indicates that ${ }^{239,240} \mathrm{Pu}$ in the coastal area near Hainan Island is mainly originated from discharge of sedimentary particles from the small river along the east coast of the Hainan Island. The large median grain sizes in the sediments at st.29 and st.45 (104 $\mu \mathrm{m}$ and $102 \mu \mathrm{m}$, respectively) near Hainan Island compared to the four times lower values at the continental shelf (st.13, 14, 17, 31, 32, 35), imply a relatively intense hydrodynamic condition and dominated river input particles in this region. The similarly low organic matter contents in the sediment at st.29 (6.7\%) and st.45 (5.9\%) compared to the offshore sediment suggest the low biological derived particles in this area.

The spatial distribution of the PPG derived plutonium reflects its transport pathway driven by ocean current as well as different migration and deposition processes of plutonium in the corresponding sedimentary environments (Fig. 5). The contributions of PPG derived plutonium in the sediment in the continental shelf, continental slope and deep basin are estimated to be 59\%, 57\% and 66\%, respectively, which are much higher than that in the Pearl River estuary $(\sim 30 \%)$ (Wu et al., 2014), implying that the PPG derived plutonium are the dominant source of plutonium in the area away from the estuary. Higher ${ }^{239,240} \mathrm{Pu}$ concentrations $(0.258-0.592 \mathrm{mBq} / \mathrm{g})$ observed in the continental shelf compared to the continental slope and deep basin $(0.048-0.173 \mathrm{mBq} / \mathrm{g})$, indicates the different factors controlling the deposition of plutonium. It was observed that the suspended particle concentrations at the upper $200 \mathrm{~m}$ on the continental shelf are considerably higher compared to the continental slope and deep ocean (Wu et al., 2018). The measured median grain sizes in the sediment from the continental shelf (st.13,14, 17, 32, 35) were about $20 \mu \mathrm{m}$, which is higher than that in the deep ocean, suggesting relatively intense and stable hydrodynamic condition in this area. While, for continental slope (st.7, st.21) and deep ocean (st.49), higher organic matter contents (10.3\% to $18.9 \%$, with an average of $15.1 \%)$ were observed compared to that in the continental shelf $(7.4 \%$ to $9.5 \%$, 
with an average of $8.7 \%$ ), indicating the enhanced transformation/deposition of plutonium through the biogeochemical process. In the continental shelf, the intense suspending particle under the relatively intense and stable hydrodynamic condition promotes the scavenging and deposition of the PPG derived plutonium (Fig. 6), resulting in a relatively high ${ }^{239,240} \mathrm{Pu}$ concentrations. In this context, however, we can not explain the single abnormal high ${ }^{239,240} \mathrm{Pu}$ concentration in the continental slope (st.20).

The lower ${ }^{239,240} \mathrm{Pu}$ concentrations in the continental slope (st.7, st.21) and deep ocean (st.49) should be attributed to low suspended matter and weak hydrodynamic condition. A sedimentation rate of only $\sim 0.003$ $\mathrm{cm} / \mathrm{yr}$ in the deep basin in the SCS was estimated by the high-resolution seabed profiles of ${ }^{14} \mathrm{C}$ and ${ }^{210} \mathrm{~Pb}$ (PA-11; $15.43^{\circ} \mathrm{N}, 115.33^{\circ} \mathrm{E} ; 4234 \mathrm{~m}$ water depth) (Kuehl et al., 1993), which is more than one magnitude lower than that on the continental slope $(\sim 0.08 \mathrm{~cm} / \mathrm{yr})$ (Ni et al., 2019) and two orders of magnitude lower than the continental shelf $(0.326 \mathrm{~cm} / \mathrm{yr})$ (Wu et al., 2014). The low sedimentation rate causes much less scavenge of dissolved plutonium into the sediment. The high organic matter content in the deep water sediments indicates that plutonium in these sediments was mainly attributed to the biogeochemical process, i.e. deposition of the biogenic debris associated plutonium on the seafloor (Fig. 6).

\section{Conclusion and perspectives}

The ${ }^{239,240} \mathrm{Pu}$ concentrations in surface sediments in the northwestern SCS were determined to be 0.048 $-0.960 \mathrm{mBq} / \mathrm{g}$ (mean: $0.282 \pm 0.242 \mathrm{mBq} / \mathrm{g}$ ), which are basically similar to the reported values in this area and its adjacent areas. The ${ }^{239,240} \mathrm{Pu}$ in the SCS originated from both global fallout of nuclear weapons tests and close-in deposition in the PPG. The PPG derived plutonium in this region originated from continuous releases/re-suspension of the close-in deposition of the nuclear weapons tests in the PPG in the 1946-1962, which was transported by the NEC and Kuroshio Current, with a branch flow westward through the Luzon Strait to the SCS, and reach to coastal regions (Hainan coastal area), and even to the western SCS. The contribution of the PPG derived plutonium in the northwestern SCS sediment were estimated to be $39 \%$ $78 \%$ (mean: 59\%) with a higher contribution in the continental slope and shelf compared to the estuary and coastal areas. The ${ }^{239,240} \mathrm{Pu}$ concentrations in the suspended matter originated from the catchment soil significantly influence the level of ${ }^{239,240} \mathrm{Pu}$ concentration in the estuary sediment. The spatial distribution of plutonium in the offshore region of the SCS depends on the deposition process of the PPG derived plutonium. The deposition of plutonium in the continental shelf was controlled by the suspended particle concentration and hydrodynamic condition. The accumulation of plutonium in the sediment in the deep sea should be 
mainly attributed to the biogeochemical process. A more conprehensive investigation of anthropogenic radionuclides in the SCS, East China Sea, Yellow Sea and Northwest Pacific Ocean including ${ }^{236} \mathrm{U},{ }^{129} \mathrm{I}$, ${ }^{137} \mathrm{Cs}$ and ${ }^{90} \mathrm{Sr}$ are presently being implemented in our group to explore the application of multi-radionuclides in the investigation of transport, migration and sedimentation process of different sourced particles in the SCS and better interpretation of different behaviors of anthropogenic radionuclides in different marine environment and in different location in the world.

\section{Credit author statement}

Mengting Zhang: Investigation, Methodology, Writing-original draft, Writing - review \& editing, Visualization. Xiaolin Hou: Conceptualization, Writing - review \& editing, Validation, Supervision, Project administration, Funding acquisition. Jixin Qiao: Validation, Writing - review \& editing. Weichao Zhang: Investigation, Writing - review \& editing. Liuchao Zhu: Methodology.

\section{Declaration of competing interest}

The authors declare no competing financial interests.

\section{Acknowledgements}

This work was financial supported by the Chinese Academy of Sciences (No. XDB40020104, 132B61KYSB20180003), the Natural Science Foundation of China (No. 11875261) and the Ministry of Science and Technology of China (No. 2015FY110800). The seawater samples were collected onboard R/V "SHIYAN3" implementing the open research cruise NORC2018-07 supported by the NSFC Ship time Sharing Project (41749907). The authors are indebted to the captain and crew for their hospitality and friendly support.

\section{References}

Aarkrog, A., 2003. Input of anthropogenic radionuclides into the World Ocean. Deep Sea Res. Part II 50(17/21), 2597-2606. https://doi.org/10.1016/S0967-0645(03)00137-1.

An, Z.S., Colman, S.M., Zhou, W.J., Li, X.Q., Brown E.T, Jull, A J T., Cai, Y.J., Huang, Y.S., Lu, X.F., Chang, H., Song, Y.G., Sun, Y.B., Xu, H., Liu, W.G., Jin, Z.D., Liu, X.D., Cheng, P., Liu, Y., Ai, L., Li, X.Z., Liu, X.J., Yan, L.B., Shi, Z.G., Wang, X.L., Wu, F., Qiang, X.K., Dong, J.B., Lu, F.Y., Xu, X.W., 2012. Interplay between the Westerlies and Asian monsoon recorded in Lake Qinghai sediments since 32 ka. Sci. Rep. 2 , 619. 
https://doi.org/10.1038/srep00619.

Boulyga, S.F., Erdmann, N., Funk, H., Kievets, M.K., Lomonosova, E.M., Mansel, A., Trautmann, N., Yaroshevich, O.I., Zhu, I.V., 1997. Determination of isotopic composition of plutonium in hot particles of the Chernobyl area. Radiat. Meas. 28, 349-352. https://doi.org/10.1016/S1350-4487(97)00098-X.

Buesseler, K.O., 1997. The isotopic signature of fallout plutonium in the North Pacific, J. Environ. Radioact. 36(1), 69-83. https://doi.org/10.1016/S0265-931X(96)00071-9

Buesseler, K.O., Sholkovitz, E.R., 1987. The geochemistry of fallout plutonium in the north Atlantic: II. ${ }^{240} \mathrm{Pu} /{ }^{239} \mathrm{Pu}$ ratios and their significance. Geochim. Cosmochim. Acta 51, 623-2637. https://doi.org/10.1016/0016-7037(87)90144-X

Cao, L.G., Zheng, J., Zhou, Z.C., Bu, W.T., Wang, Z.T., Zheng, W., Yamada, M., 2021. Distribution and behavior of plutonium isotopes in Western Pacific marginal seas. Catena 198, 105023. https://doi.org/10.1016/j.catena.2020.105023.

Diamond, H., Fields, P.R., Stevens, C.S., Studier, M.H., Fried, S.M., Inghram, M.G., Hess, D.C., Pyle, G.L., Mech, J.F., Manning, W.M., Ghiorso, A., Thompson, S.G., Higgins, G.H., Seaborg, G.T., Browne, C.I., Smith, H.L., Spence, R.W., 1960. Heavy isotope abundances in the Mike thermonuclear device. Phys. Rev. 119, 20002004. https://doi.org/10.1103/PhysRev.119.2000

Donaldson, L.R., Seymour, A.H., Nevissi, A.E., 1997. University of Washington's radioecological studies in the Marshall Islands, 1946-1997, Health Phys. 73(1), 214-222. https://doi.org/10.1097/00004032-199707000$\underline{00018}$

Dong, W., Zheng, J., Guo, Q.J., Yamada, M., Pan, S.M., 2010. Characterization of plutonium in deep-sea sediments of the Sulu and South China Sea. J. Environ. Radioact. 101, 622-629. https://doi.org/10.1016/j.jenvrad.2010.03.011

Folk, R.L., Ward, W.C., 1957. Brazos River bar: A study in the significance of grain size parameters. J. Sed. Petrol. 27, 3-26. https://doi.org/10.1306/74D70646-2B21-11D7-8648000102C1865D

Guan,Y.J., Mai, J.Y., Wang, H.J., Zhang, P.J., Huang, C.P., Liu, Z.Y., Zhan, X.Y., De Cesare, M., He, X.W., Wang, X.G., Ye, M., 2021. Plutonium isotopes and radionuclides in corals around Weizhou land in Beibu Gulf, China. Appl. Radiat. Isot. 176, 109873. https://doi.org/10.1016/j.apradiso.2021.109873

Hirose, K., Aoyama, M., Sugimura, Y., 1990. Plutonium and cesium isotopes in river waters in Japan. J. Radioanal. Nucl. Chem. 141(1), 191-202. https://doi.org/10.1007/BF02060198

Hu, J.Y., Kawamura, H., Hong, H.S., Qi, Y.Y., 2000. A review on the currents in the South China Sea: seasonal 
circulation, South China Sea warm current and Kuroshio intrusion. J. Oceanogr. 56(6), 607-624. https://doi.org/10.1023/A:1011117531252

Kelley, J.M., Bond, L.A., Beasley, T.M., 1999. Global distribution of Pu isotopes and ${ }^{237}$ Np. Sci. Total Environ. 237-238, 483-500. https://doi.org/10.1016/S0048-9697(99)00160-6

Krey, P.W., Hardy, E.P., Pachucki, C., Rourke, F., Coluzza, J., Benson, W.K., 1976. Mass Isotopic Composition of Global Fallout Plutonium in Soil. Transuranium Nuclides in the Environment. IAEA-SM-199/39. IAEA, Vienna, pp. 671-678.

Kuehl, S.A., Fuglseth, T.J., Thunell, R.C., 1993. Sediment mixing and accumulation rates in the Sulu and South China Sea: implications for organic carbon preservation in deep-sea environments. Mar. Geol. 111, 15-35 https://doi.org/10.1016/0025-3227(93)90186-Y

Lachner, J., Christl, M., Bisinger, T., Michel, R., Synal, H.A., 2010. Isotopic signature of plutonium at bikini atoll. Appl. Radiat. Isot. 68(6), 979-983.https://doi.org/10.1016/j.apradiso.2010.01.043

Lindahl, P., Worsfold, P., Keith-Roach, M., Andersen, M.B., Kershaw, P., Leonard, K., Choi, M.S., Boust, D., Lesueur, P., 2011. Temporal record of Pu isotopes in inter-tidal sediments from the northeastern Irish Sea. Sci. Total Environ. 409(23), 5020-5025. https://doi.org/10.1016/j.scitotenv.2011.08.019

Liu, Z.F., Zhao, Y.L., Colin, C., Stattegger, K., Wiesner, M.G., Huh, C.A., Zhang, Y.W., Li, X.J., Sompongchaiyakul, P.J., You C.F., Huang, C.Y., Liu, J.T., Siringan, F.P., Le, K.P., Sathiamurthy, E., Hantoro, W.S., Liu, J.G., Tuo, S.T., Zhao, S.H., Zhou, S.W., He, Z.D., Wang, Y.C., Bunsomboonsakul, S., Yanli Li, Y.L., 2016. Source-to-sink transport processes of fluvial sediments in the South China Sea. Earth-Sci. Rev. 153, 238-273. https://doi.org/10.1016/j.earscirev.2015.08.005.

Liu, Z.Y., Hu, J., Yamada, M., Yang, G.S., 2020. Uranium and plutonium isotopes and their environmental implications in surface sediments from the Yangtze River catchment and estuary. Catena 193, 104605. https://doi.org/ 10.1016/j.catena.2020.104605.

Liu, Z.Y., Zheng, J., Pan, S.M., Dong, W., Yamada, M., Aono, T., Guo, Q.J., 2011. Pu and ${ }^{137} \mathrm{Cs}$ in the Yangtze River Estuary sediments: distribution and source identification. Environ. Sci. Technol. 45 (5), 1805-1811. https://doi.org/10.1021/es1035688.

Livingston, H.D., Povinec, P.P., Toshimichi, I., Togawa, O., 2001. The behaviour of plutonium in the Pacific Ocean. Plutonium in the Environment, 1, 267-292. https://doi.org/10.1016/S1569-4860(01)80019-X

Moon, D.S., Hong, G.H., Kim, Y.I., Baskaran, M., Chung, C.S., Kim, S.H., 2003. Accumulation of anthropogenic and natural radionuclides in bottom sediments of the Northwest Pacific Ocean. Deep-Sea Res., Part II 50(17- 
Muramatsu, Y., Hamilton, T., Uchida, S., Tagami, K., Yoshida, S., Robinson, W., 2001. Measurement of ${ }^{240} \mathrm{Pu} /{ }^{239} \mathrm{Pu}$ isotopic ratios in soil from the Marshall Islands using ICP-MS. Sci. Total Environ. 278, 15-159. https://doi.org/10.1016/S0048-9697(01)00644-1

Ni, J.Y., Zhao, Jun, Jiang, Q.W., Yao, X.Y., 2019. Biogenic barium, carbon and nitrogen isotopes features in sediments of the northern South China Sea and their correlation with primary productivity of surface ocean. Haiyang Xucbao, 41(2), 41-51, (in Chinese with English abstract)_https://doi.org/0.3969/j,issn.0253$\underline{4193.2019 .02 .004}$

Noshkin, V.E., Wong, K.M., Eagle, R.J., 1979. Plutonium concentrations in fish and seawater from Kwajalein Atoll. Health Phys. 37(4), 549-56. https://doi.org/10.1097/00004032-197910000-00007

Qiao, J.X., Hansen, V., Hou, X.L., Aldahan, A., Possnert, G., 2012. Speciation analysis of ${ }^{129}$ I, ${ }^{137} \mathrm{Cs},{ }^{232} \mathrm{Th},{ }^{238} \mathrm{U}$, ${ }^{239} \mathrm{Pu}$ and ${ }^{240} \mathrm{Pu}$ in environmental soil and sediment. Appl. Radiat. Isot. 70(8), 1698-1708. https://doi.org/10.1016/j.apradiso.2012.04.006

Qiao, J.X., Hou, X.L., Miro, M., Roos, P., 2009. Determination of plutonium isotopes in waters and environmental solids. A review. Anal. Chim. Acta 652(1-2), 66-84. https://doi.org/10.1016/ j.aca.2009.03.010

Robison, W.L., Noshkin, V.E., 1999. Radionuclide characterization and associated dose from long-lived radionuclides in close-in fallout delivered to the marine environment at Bikini and Enewetak Atolls. Sci. Total Environ. 237-238(4): 311-327.https://doi.org/10.1016/S0048-9697(99)00145-X

Roviello, V., De Cesare, M., D’Onofrio, A., Gialanella, L., Guan, Y.J., Roos, P., Ruberti, D., Sabbarese, C., Terrasi, F., 2020. New analytical methods for the assessment of natural $\left({ }^{238} \mathrm{U},{ }^{232} \mathrm{Th},{ }^{226} \mathrm{Ra},{ }^{40} \mathrm{~K}\right)$ and anthropogenic $\left({ }^{137} \mathrm{Cs}\right)$ radionuclides as actinides $\left({ }^{239} \mathrm{Pu},{ }^{240} \mathrm{Pu}\right)$ : The case study of the Garigliano NPP releases along the Domitia sandy beaches (Southern Italy). Catena 193, 104612. https://doi.org/10.1016/j.catena.2020.104612

Sanchez-Cabeza, J., Merino, J., Masque, P., Mitchell, P.I., Vintro, L.L., Schell, W.R., Cross, L., Calbet, A., 2003. Concentrations of plutonium and americium in plankton from the western Mediterranean Sea. Sci. Total Environ. 311(1-3), 233-245. https://doi.org/10.1016/S0048-9697(03)00053-6

Sholkovitz, E.R., 1983. The geochemistry of plutonium in fresh and marine water environments. Earth-Sci. Rev. 19(2), 95-161. https://doi.org/10.1016/0012-8252(83)90029-6

Smith, J.N., Ellis, K.M., Naes, K., Matishov, D., 1995. Sedimentation and mixing rates of radionuclides in Barents Sea sediments off Novaya Zemlya. Deep Sea Research Part II 42(6), 1471-1493. https://doi.org/ 10.1016/09670645(95)00050-X 
Srncik, M., Tims, S.G., De Cesare, M., Fifield, L.K., 2014. First measurements of ${ }^{236}$ U concentrations and ${ }^{236} \mathrm{U} /{ }^{239} \mathrm{Pu}$ isotopic ratios in a Southern Hemisphere soil far from nuclear test or reactor sites. J. Environ. Radioact. 132, 108-114. https://doi.org/10.1016/j.jenvrad.2014.02.022

Sun, Y., Lu, H. Y., An, Z.S., 2006. Grain size of loess, palaeosol and red clay deposits on the Chinese loess plateau: significance for understanding pedogenic alteration and palaeomonsoon evolution. Palaeogeogr. Palaeoclimatol. Palaeoecol. 241, 129-138. https://doi.org/10.1016/j.palaeo.2006.06.018.

Tims, S.G., Froehlich, M.B., Fifield, L.K., Wallner, A., De Cesare, M., 2016. ${ }^{236} \mathrm{U}$ and ${ }^{239,240} \mathrm{Pu}$ ratios from soils around an Australian nuclear weapons test site, J. Environ. Radioact. 151, 563-567. https://doi.org/10.1016/j.jenvrad.2015.06.020

Wang, J.L., Baskaran, M., Hou, X.L., Du, J.Z., Zhang, J., 2017. Historical changes in ${ }^{239} \mathrm{Pu}$ and ${ }^{240} \mathrm{Pu}$ sources in sedimentary records in the East China Sea: implications for provenance and transportation. Earth Planet. Sci. Lett. 466, 32-42. https://doi.org/10.1016/j.eps1.2017.03.005

Wang, Z.L., Yamada, M., 2005. Plutonium activities and ${ }^{240} \mathrm{Pu} /{ }^{239} \mathrm{Pu}$ atom ratios in sediment cores from the East China Sea and Okinawa Trough: sources and inventories. Earth Planet. Sci. Lett. 233, 44-453. https://doi.org/10.1016/j.epsl.2005.02.024.

Warneke, T., Croudace, I.W., Warwick, P.E., Taylor, R.N., 2002. A new ground-level fallout record of uranium and plutonium isotopes for northern temperate latitudes. Earth Planet. Sci. Lett. 203(3-4), 1047-1057. https://doi.org/10.1016/S0012-821X(02)00930-5

Wendel, C.C., Fifield, L.K., Oughton, D.H., Lind, O.C., Skipperud, L., Bartnicki, J., Tims, S.G., Høibråten, S., Salbua, B., 2013. Long-range tropospheric transport of uranium and plutonium weapons fallout from Semipalatinsk nuclear test site to Norway. Environ Int. 59, 92-102. https://doi.org/10.1016/j.envint.2013.05.017

Wolf, S.F., Bates, J.K., Buck, E.C., Dietz, N.L., Fortner, J.A., Brown, N.R., 1997. Physical and chemical characterization of actinides in soil from Johnston Atoll. Environ. Sci. Technol. 31(2), 467-471. https://doi.org/10.1021/es960295+

Wu, F., Zheng, J., Liao, H., Yamada, M., 2010. Vertical distributions of plutonium and ${ }^{137}$ Cs in lacustrine sediments in northwestern China: quantifying sediment accumulation rates and source identifications. Environ. Sci. Technol. 44, 2911-2917.https://doi.org/10.1021/es9029649.

Wu, J.W., Dai, M.H., Xu, Y., Zheng, J., 2018. Sources and accumulation of plutonium in a large Western Pacific marginal sea: the South China Sea. Sci. Total Environ. 610-611, 200-211. 
https://doi.org/10.1016/j.scitotenv.2017.07.226

Wu, J.W., Zheng, J., Dai, M.H., Huh, C.A., Chen, W.F., Tagami, K.K., Uchida, S., 2014. Isotopic composition and distribution of plutonium in Northern South China Sea sediments revealed continuous release and transport of from Pu the Marshall Islands. Environ. Sci. Technol. 48, 3136-3144. https://doi.org/10.1021/es405363q.

Xing, S., Zhang, W.C., Qiao J.X., Hou, X.L., 2018. Determination of ultra-low level plutonium isotopes $\left({ }^{239} \mathrm{Pu}\right.$, ${ }^{240} \mathrm{Pu}$ in environmental samples with high uranium. Talanta, 187, 357-364. https://doi.org/10.1016/j.talanta.2018.05.05

Xu, Y.H., Pan, S.M., Gao, J.H., Hou, X.L., Ma, Y.F., Hao, Y.P., 2018. Sedimentary record of plutonium in the North Yellow Sea and the response to catchment environmental changes of inflow rivers. Chemosphere, 207, 130-138. https://doi.org/ 10.1016/j.chemosphere.2018.05.082.

Xu, Y.H., Qiao, J.X., Hou, X.L., Pan, S.M., 2013. Plutonium isotopes in soils from Northeast China and its potential application for evaluation of soil erosion. Sci. Rep. 3, 3506. https://doi.org/10.1038/SREP03506.

Xu, Y.H., Qiao, J.X., Hou, X.L., Pan, S.M., Roos, P., 2014. Determination of plutonium isotopes $\left({ }^{238} \mathrm{Pu},{ }^{239} \mathrm{Pu}\right.$, ${ }^{240} \mathrm{Pu},{ }^{241} \mathrm{Pu}$ ) in environmental samples using radiochemical separation combined with radiometric and mass spectrometric measurements. Talanta 119(3), 590-595. https://doi.org/10.1016/j.talanta.2013.11.061

Yamada, M., Oikawa, S., Shirotani, Y., Kusakabe, M., Shindo, K., 2021. Transuranic nuclides Pu, Am and Cm isotopes, and ${ }^{90} \mathrm{Sr}$ in seafloor sediments off the Fukushima Daiichi Nuclear Power Plant during the period from 2012 to 2019. J. Environ. Radioact. 227, 106459. https://doi.org/10.1016/j.jenvrad.2020.106459

Yamada, M., Zheng, J., Wang, Z.L., 2006. ${ }^{137} \mathrm{Cs},{ }^{239+240} \mathrm{Pu}$ and ${ }^{240} \mathrm{Pu} /{ }^{239} \mathrm{Pu}$ atom ratios in the surface waters of the western North Pacific Ocean, eastern Indian Ocean and their adjacent seas. Sci. Total Environ. 366(1), 242252. https://doi.org/10.1016/j.scitotenv.2005.08.014

Zhang, K.X., Pan, S.M., Liu, Z.Y., Li, G.S., Xu, Y.H., Hao, Y.P., 2018. Vertical distributions and source identification of the radionuclides ${ }^{239} \mathrm{Pu}$ and ${ }^{240} \mathrm{Pu}$ in the sediments of the Liao River estuary, China. J. Environ. Radioact. 181, 78-84. https://doi.org/10.1016/j.jenvrad.2017.10.016.

Zhang, W., Wei, X.Y., Zheng, J.H., Zhu, Y.L., Zhang, Y.J., 2012. Estimating suspended sediment loads in the Pearl River Delta region using sediment rating curves. Cont. Shelf Res. 38, 35-46. https://doi.org/ $\underline{10.1016 / \mathrm{j} . \mathrm{csr} \cdot 2012.02 .017}$

Zhang, W.C., Hou, X.L., 2019. Level, distribution and sources of plutonium in the coastal areas of China. Chemosphere 230, 587-595. https://doi.org/10.1016/j.chemosphere.2019.05.094

Zhang, W.C., Xing, S., Hou, X.L., 2019. Evaluation of soil erosion and ecological rehabilitation in loess plateau 
514 region in northwest china using plutonium isotopes. Soil Tillage Res. 191, 162-170.

$515 \quad$ https://doi.org/10.1016/j.still.2019.04.004.

516 Zhao, X., Hou, X.L., Du, J.Z., Fan, Y.K., 2019. Anthropogenic ${ }^{129} \mathrm{I}$ in the sediment cores in the East China Sea:

517 sources and transport pathways. Environ. Pollut. 245, 443-452. https://doi.org/10.1016/j.envpol.2018.11.018

518 Zheng, J., Aono, T., Uchida, S., Zhang, J., Honda, M.C., 2012. Distribution of Pu isotopes in marine sediments in

519 the Pacific $30 \mathrm{~km}$ off Fukushima after the Fukushima Daiichi nuclear power plant accident. Geochem. J. 46,

520 361-369. https://doi.org/10.2343/geochemj.2.0209

521

522

523

524

525

526

527

528

529

530

531

532

533

534

535

536

537

538

539

540 


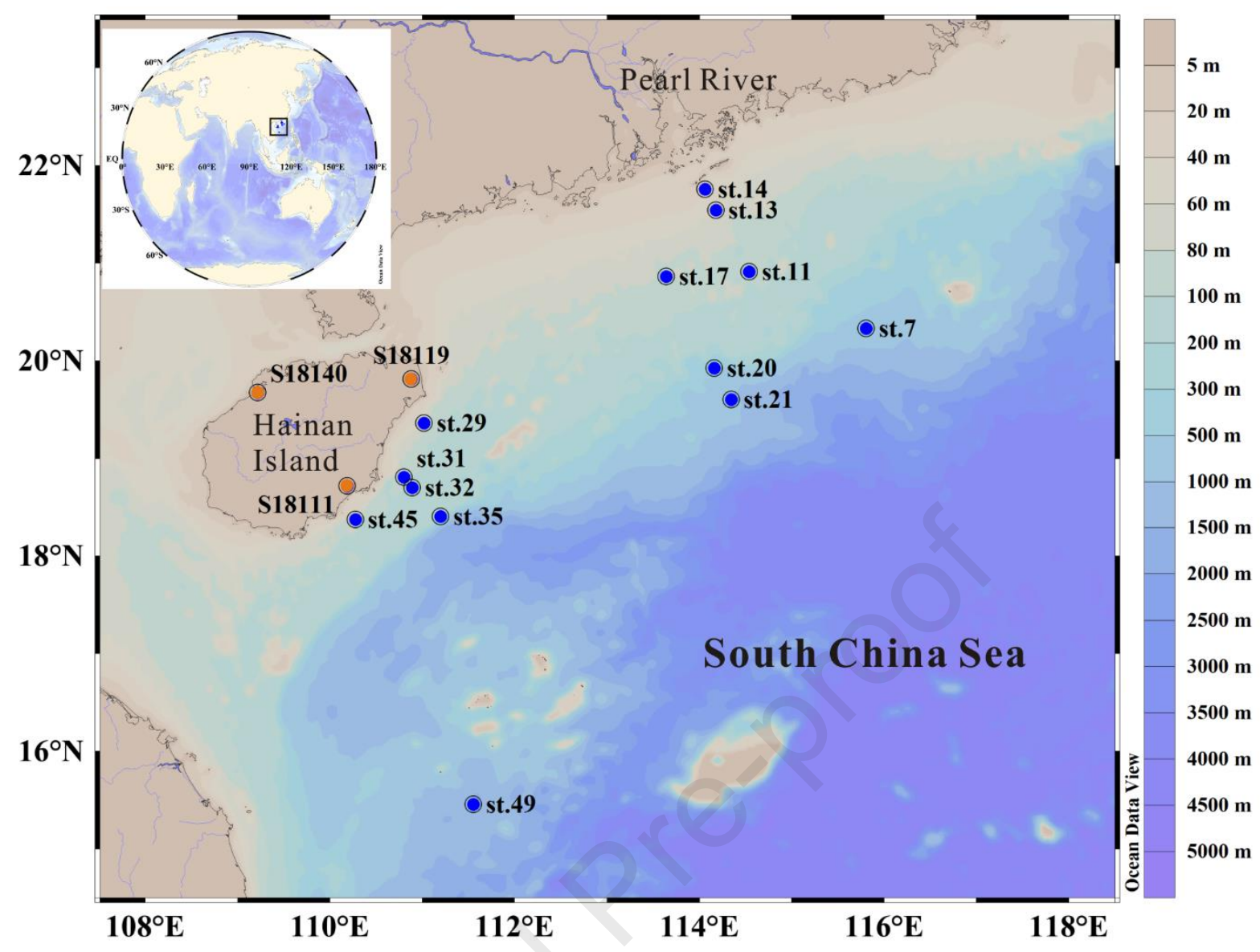

Fig. 1. Sampling sites of surface sediments (blue dots) in the South China Sea and surface soils (yellow dots) in Hainan Island 


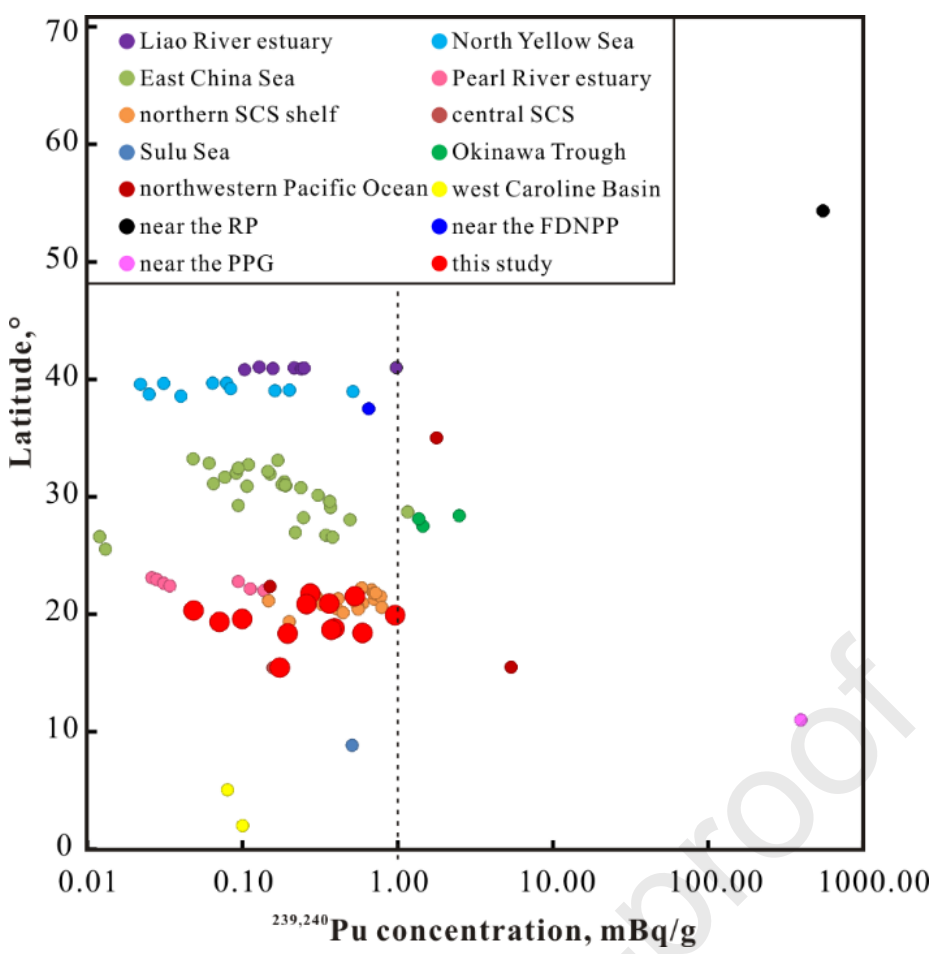

556 Fig. 2. Comparison of the ${ }^{239,240} \mathrm{Pu}$ concentrations determined in surface sediment samples in the

557 northwestern South China Sea (this work) with the reported values in the sediment, as a function of latitude.

558 The reported data are from Zhang et al., 2018; Xu et al., 2018; Wang et al., 2017; Wang and Yamada, 2005;

559 Wu et al., 2014; Dong et al., 2010; Moon et al., 2003; Lindahl et al., 2011; Yamada et al., 2021; Lachner et al., 2010 . 


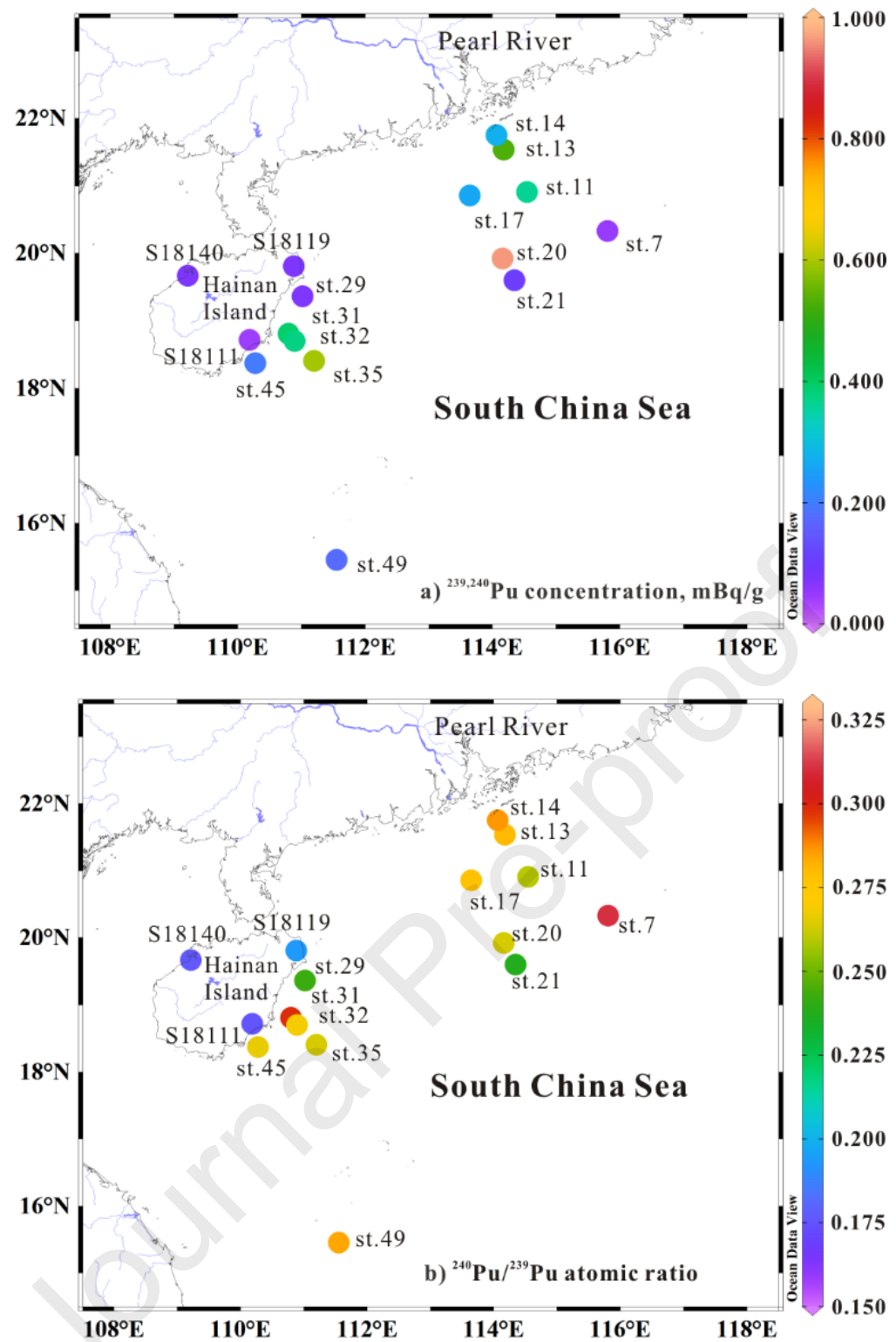

562 Fig. 3. Distributions of a) the ${ }^{239,240} \mathrm{Pu}$ concentrations and b) the ${ }^{240} \mathrm{Pu} /{ }^{239} \mathrm{Pu}$ atomic ratios in surface sediments from the northwestern South China Sea and surface soils from the Hainan Island. 


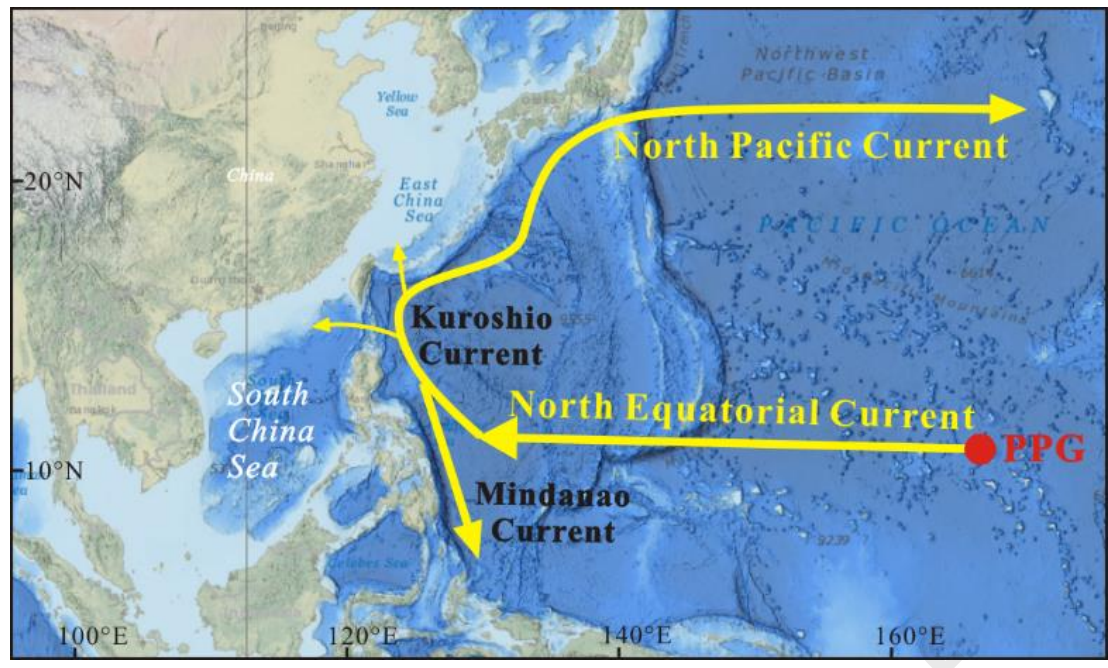

Fig. 4. Transport pathway of the PPG derived plutonium in the western Pacific Ocean

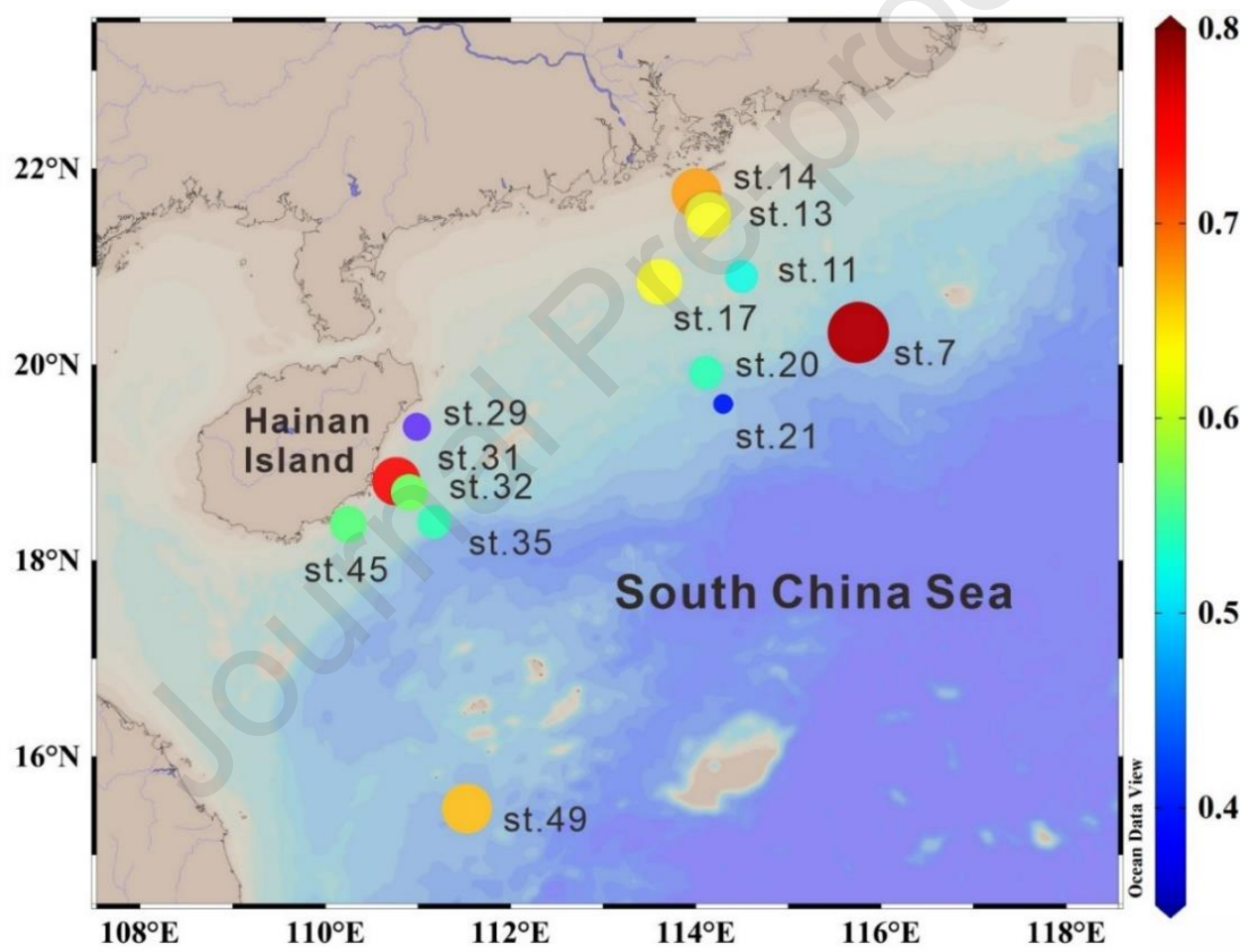

Fig. 5. Contribution (fraction) of the PPG derived plutonium in the sediments in the northwestern South

\section{China Sea.}




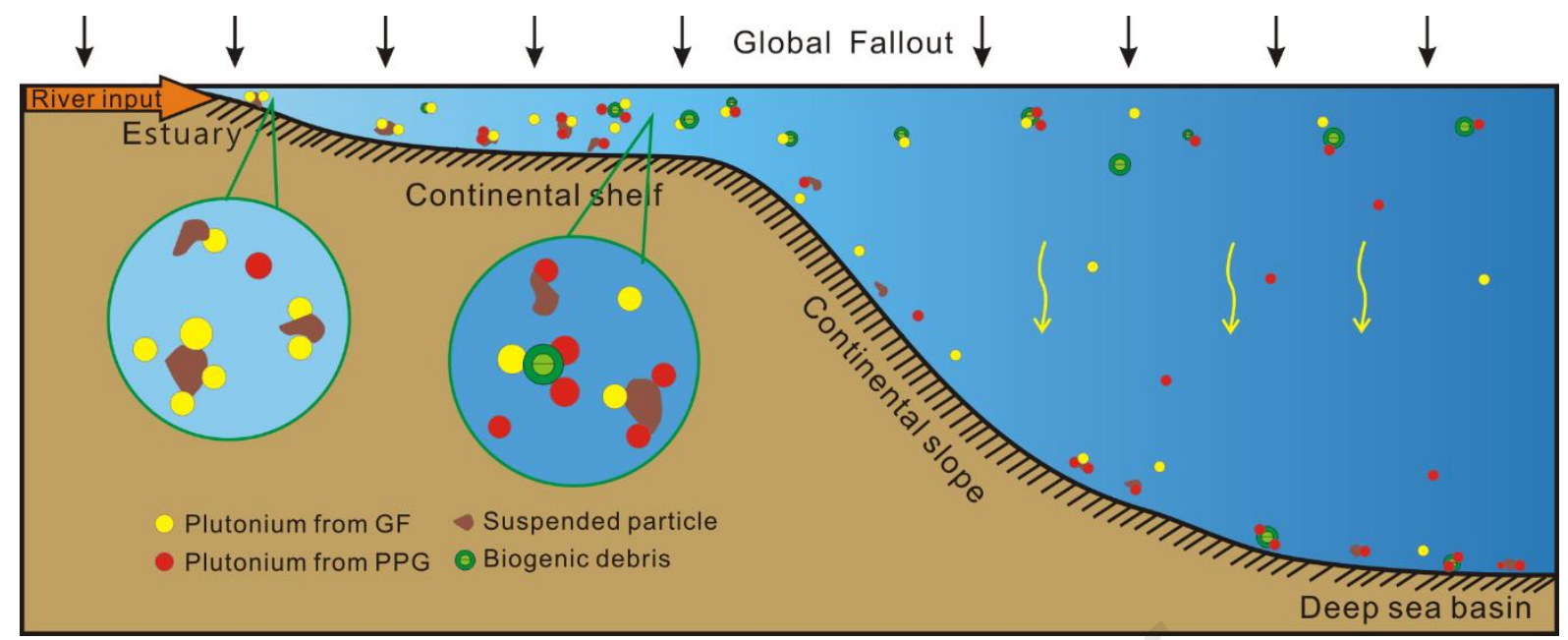

Fig. 6. Conceptual model of plutonium transport and deposition in the South China Sea

576

579

580

581

582

583

584

585

586

587

588

589

590

591

592

593

594

595 
Table 1. Sampling information, concentrations of ${ }^{239,240} \mathrm{Pu}$ and ${ }^{240} \mathrm{Pu} /{ }^{239} \mathrm{Pu}$ atomic ratios in the surface sediment collected from the South China Sea and soil from Hainan Island.

\begin{tabular}{ccccccccc}
\hline \multirow{2}{*}{ Area } & $\begin{array}{c}\text { Sample } \\
\text { code }\end{array}$ & $\begin{array}{c}\text { Latitude } \\
\left({ }^{\circ} \mathrm{N}\right)\end{array}$ & $\begin{array}{c}\text { Longitude } \\
\left({ }^{\circ} \mathrm{E}\right)\end{array}$ & $\begin{array}{c}\text { Sampling } \\
\text { date }\end{array}$ & $\begin{array}{c}\text { Bottom } \\
\text { depth } \\
(\mathrm{m})\end{array}$ & $\begin{array}{c}{ }^{239,240} \mathrm{Pu} \\
(\mathrm{mBq} / \mathrm{g})\end{array}$ & $\begin{array}{c}{ }^{240} \mathrm{Pu} /{ }^{239} \mathrm{Pu} \\
\text { atomic ratio }\end{array}$ & $\begin{array}{c}\text { Organic } \\
\text { matter } \\
(\%)\end{array}$ \\
\hline \multirow{6}{*}{ South } & st.7 & 20.330 & 115.808 & $2018 / 8 / 19$ & 650 & $0.048 \pm 0.008$ & $0.310 \pm 0.101$ & 10.3 \\
& st.11 & 20.909 & 114.541 & $2018 / 8 / 20$ & 83 & $0.361 \pm 0.031$ & $0.259 \pm 0.039$ & 9.3 \\
& st.13 & 21.540 & 114.180 & $2018 / 8 / 20$ & 56 & $0.528 \pm 0.024$ & $0.280 \pm 0.025$ & 8.7 \\
& st.14 & 21.753 & 114.063 & $2018 / 8 / 20$ & 41 & $0.273 \pm 0.011$ & $0.286 \pm 0.023$ & 7.4 \\
& st.17 & 20.860 & 113.643 & $2018 / 8 / 20$ & 81 & $0.258 \pm 0.017$ & $0.278 \pm 0.036$ & 8.0 \\
& st.21 & 19.921 & 114.162 & $2018 / 8 / 21$ & 475 & $0.960 \pm 0.032$ & $0.263 \pm 0.016$ & 9.0 \\
& st.29 & 19.603 & 114.345 & $2018 / 8 / 22$ & 943 & $0.099 \pm 0.010$ & $0.237 \pm 0.050$ & 16.1 \\
& st.31 & 18.805 & 111.020 & $2018 / 8 / 23$ & 67 & $0.071 \pm 0.006$ & $0.242 \pm 0.044$ & 6.7 \\
& st.32 & 18.700 & 110.894 & $2018 / 8 / 23$ & 111 & $0.372 \pm 0.018$ & $0.268 \pm 0.026$ & 8.8 \\
& st.35 & 18.404 & 111.201 & $2018 / 8 / 23$ & 193 & $0.592 \pm 0.018$ & $0.263 \pm 0.016$ & 9.1 \\
& st.45 & 18.373 & 110.275 & $2018 / 8 / 25$ & 85 & $0.195 \pm 0.014$ & $0.266 \pm 0.038$ & 5.9 \\
& st.49 & 15.453 & 111.552 & $2018 / 9 / 21$ & 1255.8 & $0.173 \pm 0.021$ & $0.284 \pm 0.068$ & 18.9 \\
\hline \multirow{2}{*}{ Hainan } & S18111 & 18.716 & 110.189 & $2018 / 12 / 5$ & $/$ & $0.043 \pm 0.007$ & $0.175 \pm 0.057$ & 12.0 \\
& S18119 & 19.809 & 110.882 & $2018 / 12 / 6$ & $/$ & $0.073 \pm 0.009$ & $0.193 \pm 0.044$ & 7.5 \\
& S18140 & 19.671 & 109.218 & $2018 / 12 / 8$ & $/$ & $0.072 \pm 0.007$ & $0.176 \pm 0.042$ & 8.0 \\
\hline
\end{tabular}


Table 2 Granulometric composition of the surface sediment

\begin{tabular}{|c|c|c|c|c|c|c|}
\hline Area & Station & $\begin{array}{c}\text { Water depth } \\
\text { (m) }\end{array}$ & $\begin{array}{c}\text { Clay }<4 \mu \mathrm{m} \\
(\%)\end{array}$ & $\begin{array}{c}\text { Silt } 4-63 \mu \mathrm{m} \\
(\%)\end{array}$ & $\begin{array}{c}\text { Sand }>63 \mu \mathrm{m} \\
(\%)\end{array}$ & $\begin{array}{c}\text { Median grain } \\
\text { size }(\mu \mathrm{m})\end{array}$ \\
\hline Near the & st.29 & 67 & 12.91 & 29.3 & 57.83 & 104.0 \\
\hline estuary & st. 45 & 85 & 13.15 & 27.81 & 59.03 & 102.0 \\
\hline \multirow{6}{*}{$\begin{array}{c}\text { Continental } \\
\text { Shelf }\end{array}$} & st.13 & 56 & 19.81 & 49.13 & 31.07 & 20.3 \\
\hline & st.14 & 41 & 20.55 & 53.18 & 26.28 & 17.3 \\
\hline & st.17 & 81 & 16.95 & 45.48 & 36.45 & 25.2 \\
\hline & st. 31 & 96 & 34.3 & 62.64 & 3.46 & 7.8 \\
\hline & st. 32 & 111 & 20.93 & 50.76 & 28.31 & 17.6 \\
\hline & st. 35 & 193 & 14.65 & 74.99 & 10.37 & 22.0 \\
\hline \multirow{3}{*}{$\begin{array}{c}\text { Continental } \\
\text { Slope }\end{array}$} & st.7 & 650 & 19.39 & 72.08 & 8.53 & 19.7 \\
\hline & st. 20 & 475 & 23.73 & 64.57 & 11.74 & 11.6 \\
\hline & st.21 & 943 & 35.74 & 62.85 & 1.42 & 6.8 \\
\hline Deep basin & st.49 & 1255.8 & 39.18 & 55.37 & 5.41 & 5.9 \\
\hline
\end{tabular}


Highlights:

- Distribution of ${ }^{239,240} \mathrm{Pu}$ and ${ }^{240} \mathrm{Pu} /{ }^{239} \mathrm{Pu}$ ratio in the SCS sediment were reported

- The close-in fallout of PPG contributed $39-78 \%$ of Pu in the SCS

- PPG derived Pu was transported to the SCS through NEC and KC

- $\mathrm{Pu}$ in the estuary sediment dominated by the global fallout $\mathrm{Pu}$ from the catchment

- Suspended particles and hydrodynamics influenced the deposition of $\mathrm{Pu}$ in the shelf 


\section{Declaration of interests}

$\bigotimes$ The authors declare that they have no known competing financial interests or personal relationships that could have appeared to influence the work reported in this paper.

$\square$ The authors declare the following financial interests/personal relationships which may be considered as potential competing interests:

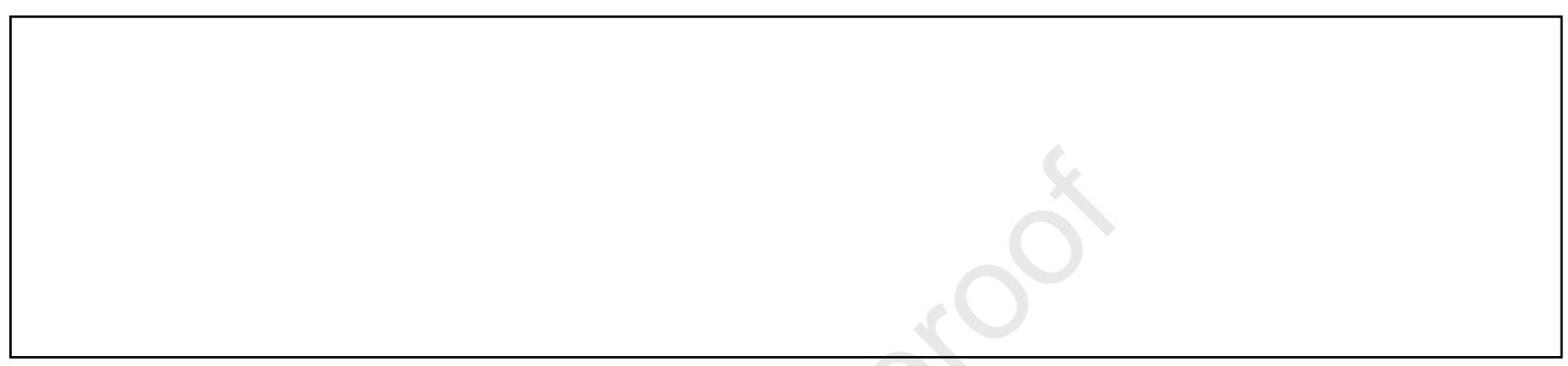

